\title{
IDENTIFYING HIGH-VALUE GREENSPACE PRIOR TO LAND DEVELOPMENT
}

\author{
by J ill R. Mahon ${ }^{1}$ and Robert W. Miller
}

Abstract. Community greenspace provides ecologic, social, and economic benefits, but these benefits are often overlooked in the land development process. As growth pressures intensify, undeveloped land is converted to other uses, often with little regard for parcels that are better suited for greenspace preservation. This paper provides a methodology for locating high-valued greenspace. Using Stevens Point, W isconsin, U.S., as a case study, significant greenspaces were identified by assessing the size, composition, and location of forests, wetlands, and grasslands in and around the urbanized area. The ecologic, recreational, and aesthetic value of each parcel was rated and the following four-part process for prioritization was developed: (1) project scope definition, (2) data collection and GIS map development, (3) data analysis and parcel ranking, and (4) protected lands overlay. Geographic information systems (GIS) technology was used as a tool to collect, store, and spatially analyze the project's data.

Key W ords. Greenspace; open space; planning; GIS; community forestry.

Community greenspace provides ecologic, social, and economic benefits (City of Calgary 1995; Arendt 1996), but these benefits are often overlooked during the land development process. I dentifying important open space and instituting a framework for its protection prior to development can help safeguard critical natural areas, preserve highly productive farmland, ensure ample recreational land and services for residents, and maintain the community's or region's historic, cultural, and natural character (Ahern 1991). Planning minimizes the need for future expenditures on pollution clean-up, restoration of degraded ecosystems, and the costly search and acquisition for properties to fulfill recreational demands of the community.

The objectives of this project were to identify greenspaces in the greater Steven s Point, W isconsin, U.S., area that are valuable for long-term protection and to develop methods for other communities to use for selecting high-priority greenspaces. Environmental Systems Research Institute's Arc/Info and ArcView GIS software (ESRI 1994) were used for data analysis and map creation.

\section{METHODS}

Part I: Project Scope Definition

$O$ pen Space. Because open space is a subjective term that could refer to land categories ranging from forest and farmland to ballfields and vacant lots, it was important to define open space and specify what types of lands would be eval uated. For this project, the terms "greenspace" and "open space" were used interchangeably to describe forests, wetlands, grass/brushlands, parks, outdoor recreation areas (both public and private), and cemeteries.

G rowth Area Boundary. A system of open space should extend across political boundaries and span urban, suburban, and rural areas (Smith 1993). The projected growth area boundary should be outlined to serve as the study area. The Stevens Point growth area boundary had been defined by local planners to include lands that will be most significantly influenced by the growing population and subsequent requirements for urban expansion through 2010 (Dwyer 1996). This 55,000-acre area has a population of about 40,000 and includes the city of Stevens Point and portions or all of nine villages and townships (villages of Whiting, Plover, and Park Ridge; towns of Hull, Stockton, Sharon, Plover, Carson, and Linwood).

$\mathrm{G}$ oals. The basis for assessing greenspace value was determined by how each parcel, if preserved, would help meet the community's long-range goals (City of Calgary 1995; Boulder County Parks and O pen Space 1996). Goals for the Stevens Point area are as follows:

1. Protect water quality and critical natural areas.

2. Provide recreational opportunities for Stevens Point area residents and visitors.

3. Develop a greenspace network that preserves the community's natural character.

4. Guide future growth and development.

Part II: Data Collection and GIS Map Development

D ata N eeds Assessment. Before any data were collected, a needs analysis and inventory of existing data resources were conducted. The types of land characteristics that make greenspace desirable for preservation were based on Stevens Point's greenspace goals. 
For Goal 1, lands that protect water quality include undeveloped areas adjacent to waterways and wetlands (Binford and Buchenau 1993; O sborne and Kovacic 1993). Critical natural areas include wetlands, parcels with rare vegetation types (Swalter et al. 1996), parcels with the potential for unique vegetation cover types, large areas of similar vegetation cover (Crow 1989), parcels with a low edge to interior ratio (Matlack 1994), parcels that connect two or more natural areas (Smith 1993; Thorne 1993), parcels with a high number of native species (Swink and Wilhelm 1994; Swalter et al. 1996), large natural areas (Schonewald-Cox and Bayless 1986), and parcels that have maintained consistent vegetation type over time.

For Goal 2, lands that provide recreational value to the community include areas adjacent to existing trails, areas accessible from existing trails, areas with a diversity of recreational opportunities, parcels located in areas currently in need of recreational opportunities, and areas easily accessible to the public.

For Goal 3, lands that are, or have the potential to become, part of a greenspace network include currently undeveloped lands and areas that link existing parks, golf courses, cemeteries, and natural areas.

Goal 4 includes lands that, if retained as greenspace, would help preserve the visual integrity and natural character of the community. Such land includes parcels with views of water (Brush and Palmer 1979), parcels that are visible from water, parcels that are visible from roadsides, parcels that represent all natural vegetation types of the area, and parcels on raised elevations and steep slopes (providing overlooking views of the community).

Final decisions regarding which land characteristics were to be included in the analysis were determined by comparing the cost of obtaining the necessary maps and information relative to its utility as an indicator of greenspace priority. This determination incorporated the time and cost for collecting and preparing the data as well as the time required for assessing each parcel's value. "Utility" was gauged according to the importance of that land characteristic in meeting criteria for community goals and the reliability of the data to describe that characteristic.

The following maps were selected for inclusion in the case study: (1) undeveloped land, (2) existing recreation trails, (3) current vegetation cover types, and (4) unique vegetation cover types.

Because all information needed to be in a compatible GIS format for overlay analysis, a standard coordinate system and units were selected. All coverages were created in or projected into the Universal Transverse M ercator (UTM) coordinate system on the North American Datum (1927), with units in meters.

Data Collection. To create the first GIS map, "undeveloped land," an existing land use/land cover map was reclassified into the following categories: developed, agricultural, forest, pine plantation, grass/brush, marsh, water, recreational, roads, utilities, and cemeteries. All undeveloped parcels were copied to a separate coverage as a basis for other data layer development and comparison.

From this map, GIS was used to buffer all intermittent streams and marshes 10.67, 21.34, and $32.00 \mathrm{~m}$ inland. Perennial streams, rivers, and lakes were buffered 30.48, 60.96 , and $91.44 \mathrm{~m}$ inland from the shoreline (approximately the ordinary high water mark). These categories of distance are based on Wisconsin's Forestry Best Management Practices for Water Qual ity (W isconsin Department of Natural Resources 1995). This hydrology layer was then intersected with the undeveloped lands layer to identify undeveloped parcels within these buffer zones.

The second GIS map, "existing recreation trails," was al ready in a digital format. This map identified the location of Stevens Point's 38.62 km Green Circle Trail. Secondary trails were not mapped. Recreation trails generally cannot be identified through air photo interpretation, but they can be mapped via global positioning systems (GPS) or digitized from existing paper maps.

The Green Circle Trail was buffered 30.48 and $60.96 \mathrm{~m}$ outward in both directions. This layer was then overlayed onto the undeveloped lands layer to discern all undeveloped lands within those two buffer distances of the trail. Determining appropriate buffer distances was difficult because visibility from trails can substantially vary depending on vegetation type, density, and vertical structure. These buffer distances were estimated based on field observations along the Green Circle Trail.

The third GIS map, "current vegetation cover types," was created by collecting field data. Forests were classified according to forest cover type categories set forth by the Society of American Foresters (Eyre 1980). W here additional categories were needed, the same naming conventions were adopted. Because species differences were not discernible from air photos, data were collected by ground surveys, windshield surveys, and low-level aircraft flights. All information was recorded on printouts of digital orthophotos and then digitized in the GIS to create another layer. All other undeveloped lands were visited and classified as wetland, grass/brush, mowed under canopy, mowed under scarce canopy ( $<20 \%$ cover), or mowed grass.

The fourth GIS map, "pre-settlement vegetation cover types," was digitized from an existing paper map created by Tesch (1982). This layer was then combined with the current vegetation cover type layer to distinguish parcels with similar vegetation types between the two time periods, to identify parcels that had pre-settlement vegetation that is currently rare, and to determine which, if any, parcels have a currently rare vegetation type that is the same as during presettlement times. 
Part III: Data Analysis and Parcel Ranking After all of the necessary information was collected and compiled into GIS maps, data were summarized so that the highest-valued parcels could be identified. This task was accomplished by assigning numeric values that represent each parcel's aesthetic, recreational, and/or ecologic worth in the greenspace system. Parcels were awarded 0 to 5 points for each criterion. Numeric values can be altered to reflect changes in priorities and incorporate criteria that were not feasible in this study.

G eneral Land U se/Land Cover. This map was used to identify undeveloped parcels located adjacent to waterways and recreation trails. Because ecologic values are based on contributions made for shoreline protection and sediment filtration (Binford and Buchenau 1993; Osborne and Kovacic 1993), ecologic value decreased with distance from waterway. Aesthetic points were assigned to parcels located within close visual proximity to waterways - for the value of providing appeal ing views of water and from water (Table 1 ). Undeveloped lands adjacent to the Green Circle Trail received recreational points because of the importance of natural views to trail users. Points were also awarded to undeveloped parcels that were accessible within $30.48 \mathrm{~m}$ of the trail. These parcels have potential as future park sites.

Cur rent Vegetation Cover. Natural areas received higher ecologic point values than monoculture and manicured landscapes because they generally provide greater diversity in species and structure and protect ecologic functions (Smith 1993). Because tree canopy is so valuable in urban areas for reducing stormwater runoff volume and velocity, thereby minimizing erosion and stream sedimentation, canopied parcels received higher ecologic scores than lesscanopied areas (Binford and Buchenau 1993; Smith 1993) (Table 2).
Wetlands and forests received the highest aesthetic scores because past studies have shown that views of water, wetlands, and trees are preferred over grass (Magill 1992). $M$ anicured landscapes are perceived as aesthetically pleasing but less so than natural landscapes. Therefore, mowed areas without canopy received lower scores than canopied areas.

Ecologic points were assigned to parcels that had vegetation cover types unique in the study area, gauged by percentage of cover. Unique vegetation also has aesthetic value (Laurie 1975). Therefore, aesthetic points were awarded to land parcels that had distinct vegetation types, in two categories of rarity based on percentage of cover. $\mathrm{N}$ atural breaks in the difference between percentage of cover were used to differentiate rarity scores.

Ecologic points were assigned to each parcel based on the contiguous land area of one cover type because species richness is greater in larger parcels. Class widths were defined based on an evaluation of the most common parcel sizes and a desire to buffer those sizes enough to include parcels slightly larger or smaller. Because the goal was to increase scores in proportion to parcel size, class increments were equal ( $6.07 \mathrm{ha}$ ). Parcels smaller than this size received a score of 0 , while parcels larger than 30.35 ha received a 5.

Pre-Settlement and Current Vegetation Comparisons. Ecologic points were given to parcels that had the same presettlement vegetation cover type as current cover type because these parcels may be influenced by the same disturbance regime as 150 years ago (Table 3). Parcels that had a pre-settlement cover type that was identified as currently rare were awarded more points because, in some cases, that rare vegetation type could be "restored" to the site. Even more points were awarded to parcels with the same pre-settlement and current vegetation cover types and where the

Table 1. Parcel ranking based on proximity to waterways and recreation trails.

\begin{tabular}{llll}
\hline Proximity & $\begin{array}{l}\text { Ecologic } \\
\text { score }\end{array}$ & $\begin{array}{l}\text { Aesthetic } \\
\text { score }\end{array}$ & $\begin{array}{l}\text { Recreational } \\
\text { score }\end{array}$ \\
\hline
\end{tabular}

Distance from intermittent stream or marsh $<10.67 \mathrm{~m}$

$10.67-21.03 \mathrm{~m}$

21.04-32.00 m

4

$\begin{array}{ll}5 & 4 \\ 4 & 3\end{array}$

Distance from perennial stream/river/lake $<30.48 \mathrm{~m}$

$30.48-60.95 \mathrm{~m}$

$60.96-91.14 \mathrm{~m}$

3 cover type was found to be currently rare in the study area. Due to the uncertainty surrounding proposals to "restore" previous vegetation cover, the aforementioned criteria were not weighted heavily (1 to 3 maximum points).

Summing Values. All land parcels were evaluated, points were awarded, and scores were then summed within the categories of ecologic, recreational, and aesthetic attributes. This procedure resulted in three separate maps, displaying parcels with the greatest ecologic, recreational, and aesthetic values. 
Table 2. Parcel ranking based on land cover and vegetation cover type.

\begin{tabular}{|c|c|c|c|}
\hline Land/vegetation cover type & $\begin{array}{l}\text { Ecologic } \\
\text { score }\end{array}$ & $\begin{array}{l}\text { Aesthetic } \\
\text { score }\end{array}$ & $\begin{array}{l}\text { Recreational } \\
\text { score* }\end{array}$ \\
\hline \multicolumn{4}{|l|}{ Land cover } \\
\hline Wetland & 5 & 5 & \\
\hline Forest & 5 & 5 & \\
\hline Pine plantation & 3 & 4 & \\
\hline Mowed under canopy & 3 & 3 & \\
\hline Mowed under scarce canopy & 2 & 2 & \\
\hline Grass/brush & 2 & 2 & \\
\hline Mowed grass & 1 & 2 & \\
\hline \multicolumn{4}{|l|}{ Rareness of vegetation type by percentage of land cover } \\
\hline Pinus sylvestris $(0.03 \%)$ & 5 & 3 & \\
\hline Acer saccharum-Tilia americana $(0.05 \%)$ & 5 & 3 & \\
\hline Picea glauca $(0.07 \%)$ & 5 & 3 & \\
\hline Thuja occidentalis $(0.11 \%)$ & 5 & 3 & \\
\hline Robinia pseudoacacia $(0.14 \%)$ & 5 & 3 & \\
\hline Fraxinus nigra-U Imus americana-Acer saccharinum (0.21\%) & 5 & 3 & \\
\hline Quercus alba $(0.49 \%)$ & 5 & 3 & \\
\hline Pinus strobus- Quercus rubra-Acer rubrum (0.92\%) & 5 & 3 & \\
\hline Quercus rubra (1.62\%) & 5 & 3 & \\
\hline Larix laricina $(4.36 \%)$ & 3 & 1 & \\
\hline Pinus strobus (5.21\%) & 3 & 1 & \\
\hline Acer saccharinum, UImus americana (6.56\%) & 3 & 1 & \\
\hline Populus tremuloides (7.33\%) & 3 & 1 & \\
\hline \multicolumn{4}{|l|}{ Parcel size of contiguous cover type } \\
\hline$>30.35$ ha & 5 & & \\
\hline $24.28-30.34$ ha & 4 & & \\
\hline $18.21-24.27 \mathrm{ha}$ & 3 & & \\
\hline $12.14-18.20$ ha & 2 & & \\
\hline $6.07-12.13 \mathrm{ha}$ & 1 & & \\
\hline
\end{tabular}

Weighting Ecologic, Recreational, and Aesthetic Values Equally. For this study, all goals were equally important, meaning that protecting water quality was deemed as important as providing recreational opportunities for residents and as important as preserving the natural character of the community. Therefore, scores were weighted equally among the ecologic, recreational, and aesthetic values before being summed to create one map of the highest-priority parcels.

W ith varying numbers of criteria, the maximum score possible for ecologic value was 22 , for aesthetic value was 13 , and for recreational value was 5 . To standardize the data set, each parcel's ecologic, recreational, and aesthetic raw scores were converted to a 100-point scale. Ecologic, aesthetic, and recreational raw scores were divided by 22 , 13 , and 5 , respectively, and then multiplied by 100 .

Part IV: Protected Lands Overlay

Some valuable greenspaces were al ready protected, either by ownership or zoning. These lands were identified so that those without protection could receive a priority status for preservation.

Land 0 wnership. Some landowners have no intention of developing their land; as long as ownership does not change on those properties, the lands are likely to remain open space. For example, lands owned by government agencies, private outdoor recreational enterprises, and conservation organizations are likely to remain as greenspace regardless of increasing development pressures.

Locating these protected lands provided a baseline inventory from which the design of future open space could be developed. Many cities al ready have parcel records in a GIS, making it easy to identify ownership through simple database analysis. Stevens Point, however, did not have a completed digital parcel map. Protected lands were selected by searching tax-exempt records for each parcel owned by a government agency, private company, or nonprofit organization likely to withhold development on their property. Stevens Point parks were identified from the Stevens Point Comprehensive Outdoor Recreation Plan 1996-2000 (City of 
Table 3. Parcel ranking based on comparisons between pre-settlement and current vegetation cover type and cover type rarity.

\begin{tabular}{llll}
\hline Pre-settlement/current vegetation comparisons & $\begin{array}{l}\text { Ecologic } \\
\text { score }\end{array}$ & $\begin{array}{l}\text { Aesthetic } \\
\text { score* }\end{array}$ & $\begin{array}{l}\text { Recreational } \\
\text { score* }\end{array}$ \\
\hline Same type, currently rare & 3 & & \\
Pre-settlement type, currently Rare & 2 & & \\
Same type, not currently rare & 1 & & \\
\hline
\end{tabular}

*Aesthetic and recreational values were not scored for this criterion. notable occurrences of distinct vegetation are the contiguous tamarack (Larix laricina) forests found in the eastern area and small patches of white oak (Quercus alba), white cedar (Thuja occidentalis), and sugar maple-basswood (Acer saccharum-Tilia americana) forests.
Stevens Point 1997), and others were mapped through roadside surveys. GIS was then used to create a digital map of these records that, when combined with the land use/land cover map, indicated all undeveloped, "protected" parcels.

Zoning. Some lands are protected from development by zoning restrictions (Portage County 1994). This map layer was created by isolating parcels zoned as "exclusive agriculture" or "conservancy" from an existing rural zoning map (Dwyer 1996).

D evel opment Limitations. Some lands have physical features and locations that make construction difficult and therefore costly. Due to the expense involved, these lands are less likely to be developed (Dan Mahoney, Areawide Planning Office, Stevens Point, WI, pers. comm. 1996). These lands include parcels in the floodplain; wetlands; and areas with steep slopes, high water table, or shallow bedrock. Lands within the floodplain can be mapped from Federal Emergency Management Administration (FEMA) maps, but the time required to improve the accuracy of these maps for conversion to GIS coverages prohibited inclusion in the study. Wetlands and areas with steep slopes (greater than 12\%), shallow bedrock (less than $1.52 \mathrm{~m}$ below surface), and/or high groundwater (less than $1.52 \mathrm{~m}$ below surface) were derived from the digital representation of the Portage County Soil Survey (USDA Soil Conservation Service 1978).

\section{RESULTS}

General Land Use/Land Cover Most of the undeveloped forest and wetland areas were located on the western side of the Wisconsin River, along the Little Plover and Plover rivers, and in the northern third of the study area, between the Wisconsin and Plover rivers (Figure 1). The southern and eastern portions of the study area were dominated by agriculture, while the middle was urban development.

\section{Vegetation Cover Types}

Most of the area is covered with red pine (Pinus resinosa) plantations and red maple (Acer rubrum), pin oak (Quercus ellipsoidalis), and jack pine (Pinus banksiana) forests. There are large patches of wetlands located on the west side of the study area, and several wetland communities were found throughout the northern and northwestern areas. The most
Pre-Settlement Vegetation

Pre-settlement vegetation in the area was primarily jack pine- pin oak forests, stretching across most of the eastern two-thirds of the study area. The northeastern corner comprised swamp conifers, while the southeastern corner was oak savanna and prairie. There was a large area of aspen-paper birch (Populus tremuloides-Betula papyrifera) in the north central area, and areas in the western portion were primarily sugar maple-basswood, with patches of sugar maple-yellow birch (Acer saccharum-Betula allegheniensis), hemlock-silver maple (Tsuga canadensis-Acer saccharinum), and swamp conifers.

Comparison Between Pre-Settlement and Current Vegetation

There are very few areas where the vegetation cover type was found to be the same as it was during pre-settlement years. Most remnants are lowland hardwoods and marshes. Large areas of land previously covered by sugar maplebasswood forests and oak openings are currently rare cover types. Most of the area is still forested, but due to the construction of dams over the past 150 years, some have been covered by water.

High-Priority Greenspace

The high-priority greenspace map identifies which parcels received the highest ratings for greenspace value (Figure 1). O ut of 300 points possible, the highest score (when ecologic, recreational, and aesthetic values are combined) was 277. Scores were grouped into 25-point increments, except scores between 0 and 75 , which were all grouped together. This classification was created to keep the increment small enough to detect differences between valued land parcels, but also to keep the number of classes low enough to discern differences in color gradations on the map.

Public Lands and Lands with Protective Zoning The largest areas of public land included the Stevens Point municipal airport, the University Reserve, Jordan County Park, W isconsin Department of $\mathrm{N}$ atural Resources' fisheries protection areas, and smaller parcels owned by the various governmental units. Private large land holdings include four golf courses, Izaak Walton League land, and land owned by two forest products companies. 


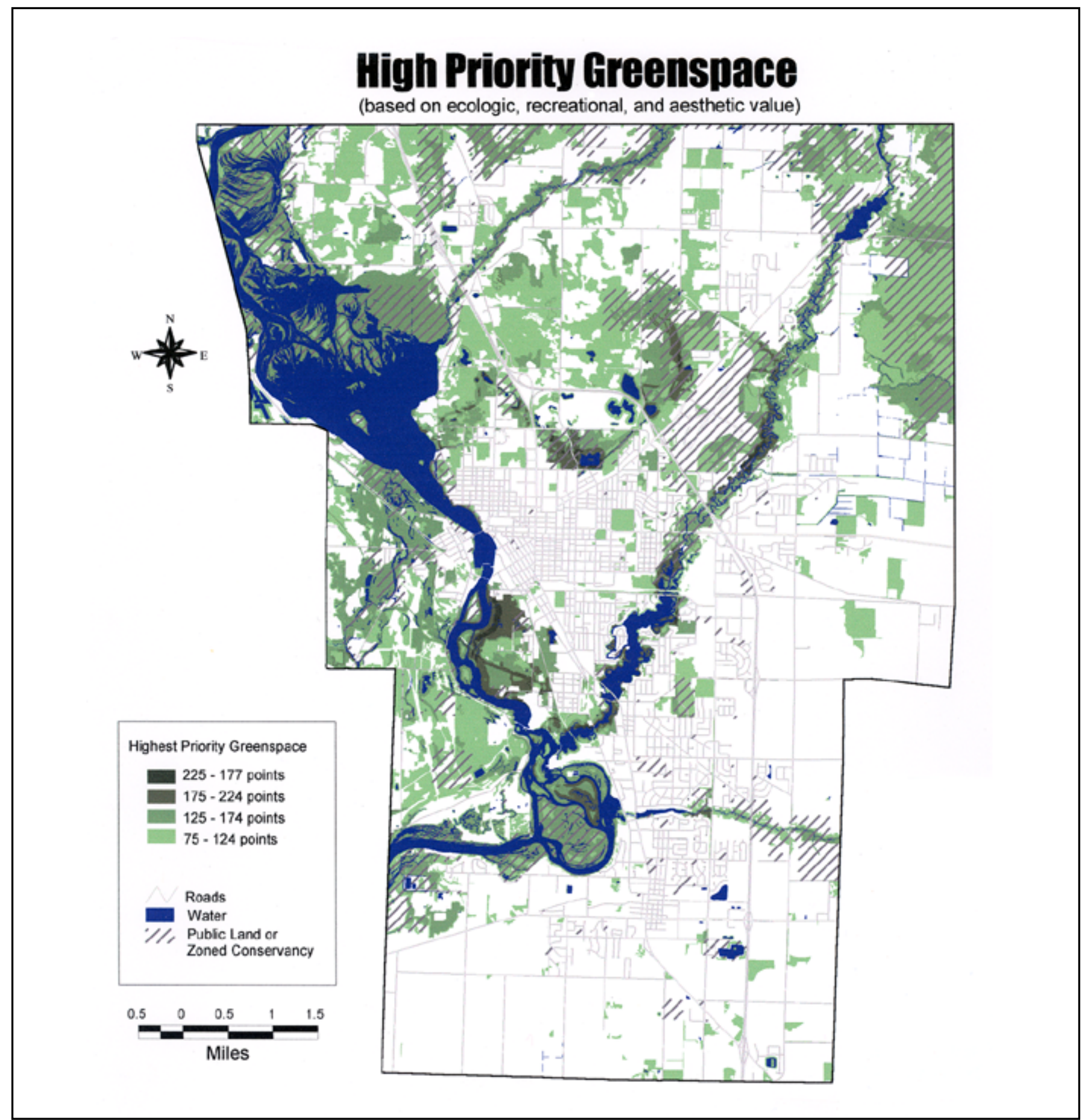

Figure 1. Parcels with the greatest ecologic, recreational, and aesthetic value as greenspace in the greater Stevens Point, Wisconsin, growth area and indications of areas currently protected under zoning and public ownership. Map by Jill Mahon, December 1998. 
Two land uses are protected through zoning: agricultural and conservancy. Lands zoned "exclusive agriculture" comprise a large area in the southwest and southeast portions of the study area. Lands zoned "conservancy" comprise most of the floodplain and wetlands in the study area.

Lands with Development Limitations

A large portion of the study area has a high water table. Two large masses of shallow bedrock are located in the northwestern and north central portions of the study area. The few steep slopes are located in the Plover River corridor south of Jordan Pond to the confluence of the $W$ isconsin River. Devel opment in these areas is normally restricted due to limitations in on-site wastewater disposal.

\section{DISCUSSION}

Ecologically important greenspace was found to be primarily located adjacent to waterways and in wetlands. However, isolated upland patches were also identified that represent areas of unique vegetation cover. Very few highpriority greenspaces were identified in the southern and eastern portions of the study area because of high prevalence of agricultural lands, which were not included in the evaluation. Even so, wetlands, forests, and grasslands in those areas should be considered for protection because of the rarity of their occurrence.

There is value in additional study of parcels in the northwestern portion of the project area where the presettlement vegetation was sugar maple-basswood but is currently forested in a variety of unique cover types, including white pine (Pinus strobus), white oak (Quercus alba), white pine-red oak-red maple (Pinus strobus- Q uercus rubraAcer rubrum), white oak, and red oak. There is also a large marsh that, despite dramatic change in the W isconsin River channel, is still a wetland and may hold even greater ecological value than realized in this study.

Areas to the west of the W isconsin River have heavier soils and, therefore, different vegetation patterns compared to the eastern side of the river. Much of the area is particularly wet, so development is difficult; the potential for successful greenspace preservation is high. Due to the configuration of the rivers, there are prime opportunities for linking natural corridors through the northern part of the study area.

Evaluation for recreationally important lands identified some large parcels on the Green Circle Trail that may provide desirable future park sites. Most of the areas identified as high priority for ecologic and/or aesthetic value could be created as natural park areas, but care should be given to those areas that are ecologically sensitive because the impact of human use may alter the status of those ecosystems (Cole 1993). It may be valuable to acquire high-priority greenspaces adjacent to existing protected lands, especially where a suitable link between areas has been identified. Because athletic fields, playgrounds, and other outdoor recreation facilities usually have few site requirements (Dan Mahoney, Areawide Planning Office, Stevens Point, WI, pers. comm. 1996), the suitability of lands for those purposes was not included in this study.

Because aesthetic preferences are highly subjective, evaluating lands and ranking value was particularly difficult. Lands adjacent to waterways and wetlands received the most points, followed by unique forest cover types. Most lands protected for ecologic and recreational value will provide aesthetic value as well.

\section{CONCLUSION}

The methods for identifying high-priority greenspace are (1) define the project scope, (2) collect and compile information into GIS maps, (3) analyze data and rank parcels, and (4) identify lands with and without protection. It is obvious that wetlands and lands adjacent to waterways and existing recreation trails have high importance as greenspace. H owever, some other areas received particularly high value and would not have been identified without the analysis used in this project. Also, the results help differentiate between land parcels with "medium" and "low" values, which may be very important when making decisions about possible routes to link high-priority areas. Although time did not permit in this project, future studies could include assessments of prime farmland, cultural resources such as prehistoric sites (Willems 1998), future trail siting, geologic features, groundwater recharge areas, and the presence of rare plant communities.

The long-term protection of these "high-priority" greenspaces is ultimately dependent on the citizens, planners, and managers of the community. Representatives from each city, village, and town jurisdiction need to cooperatively develop and implement a plan to protect open space. This plan should detail precise land parcels to be protected as open space and should prescribe the most appropriate way to secure this protection (land acquisition, purchase of development rights, zoning, etc.) (Dwyer 1996). The open space plan will serve to guide future community growth, accommodate the public need for open space, and ensure a healthy, attractive community environment. Fortunately, this project led to the formation of the grassroots organization People for Greenspace in Portage County and ultimately to the development of an Area-Wide Open Space Plan by the Portage County Planning O ffice to assist municipalities, villages, and townships in their planning efforts.

The methods outlined in this report are applicable in any community. Values will, undoubtedly, vary among communities and can be accounted for by adjustments in scores and weights. 


\section{LITERATURE CITED}

Ahern, J. 1991. Planning for an extensive open space system: Linking landscape structure and function. Landscape Urban Plann. 21:131-145.

Arendt, R. 1996. Conservation Design for Subdivisions: A Practical Guide to Creating O pen Space N etworks. Island Press, Washington DC.

Binford, M.W., and M.J. Buchenau. 1993. Riparian greenways and water resources, pp 69-104. In Smith, D.S., and P.C. Hellmund (Eds.). Ecology of Greenways: Design and Function of Linear Conservation Areas. University of Minnesota, M inneapolis, MN . 222 pp.

Boulder County Parks and Open Space. 1996. North Foothills O pen Space Management Plan. Boulder County, CO. $78 \mathrm{pp}$.

Brush, R.O., and J.F. Palmer. 1979. M easuring the impact of urbanization on scenic quality: Land-use change in the Northeast, pp 358-384. In Elsner, G.H., and R. C. Smardon (Eds.). Proceedings of O ur National Landscape: A Conference on Applied Techniques for Analysis and Management of the Visual Resource. Pacific Southwest Forest and Range Experiment Station, Berkeley, CA.

City of Calgary. 1995. Sustainable Suburbs Study: Creating More Fiscally, Socially, and Environmentally Sustainable Communities. City of Calgary Planning and Building Department, Calgary, AB.

City of Stevens Point. 1997. Stevens Point Comprehensive Outdoor Recreation Plan: 1996-2000. Stevens Point, WI. $48 \mathrm{pp}$.

Cole, D.N. 1993. Minimizing conflict between recreation and nature conservation, pp 105-122. In Smith, D.S., and P.C. Hellmund (Eds.). Ecology of Greenways: Design and Function of Linear Conservation Areas. University of Minnesota, Minneapolis, M N. 222 pp.

Crow, T.R. 1989. Landscape ecology: An eclectic science for the times, pp 30-34. In Rink, G., and C.A. Budelsky (Eds.). Proceedings of the Seventh Central Hardwood Forest Conference. 5-8 March 1989, Carbondale, IL. Gen. Tech. Rep. NC-132. USDA Forest Service, North Central Forest Experiment Station, St. Paul, M N. 304 pp.

Dwyer, M.C. 1996. An ecosystem-based urban forest model. M.S. Thesis, University of W isconsin-Stevens Point, WI. $159 \mathrm{pp}$.

Environmental Systems Research Institute, Inc (ESRI). 1994. Understanding GIS: The ARC/INFO Method. Redlands, CA. $457 \mathrm{pp}$.

Eyre, F.H. 1980. Forest Cover Types of the United States and Canada. Society of American Foresters, Washington, DC. $135 \mathrm{pp}$.
Laurie, I.C. 1975. Aesthetic factors in visual evaluation, pp 102-118. In Zube, E., R. Brush, and J. Fabos (Eds.). Landscape Assessment: Values, Perceptions, and Resources. Dowden, Hutchinson, and Ross, Inc., Stroudsburg, PA. 367 pp.

Magill, A. 1992. Managed and Natural Landscapes: W hat Do People Like? Res. Paper PSW-RP-213. USDA Forest Service, Pacific Southwest Research Station, Albany, CA. $28 \mathrm{pp}$.

Matlack, G.R. 1994. Vegetation dynamics of the forest edge - Trends in space and successional time. J. Ecol. 82:113-123.

O sborne, L.L., and D.A. Kovacic. 1993. Riparian vegetated buffer strips in water-quality restoration and stream management. Freshwater Biol. 29:243-258.

Portage County. 1994. Portage County Zoning O rdinance. Portage County Planning and Zoning, Portage County, W I.

Schonewald-Cox, C.M., and J.W. Bayless 1986. The boundary model: A geographical analysis of design and conservation of nature reserves. Biol. Conserv. 38:305-322.

Smith, D.S. 1993. An overview of greenways: Their history, ecological context, and specific functions, pp 1-22. In Smith, D.S., and P.C. Hellmund (Eds.). Ecology of Greenways: Design and Function of Linear Conservation Areas. University of Minnesota, Minneapolis, MN . 222 pp.

Swalter, R., M.D. Byer, and J.T. Tanarcredi. 1996. Rare and endangered plants at Gateway National Recreation Area: A case for protection of urban natural areas. Landscape Urban Plann. 35:41-51.

Swink, F., and G. Wilhelm. 1994. Plants of the Chicago Region: An Annotated Checklist of the Vascular Flora of the Chicago Region. Indianapolis Academy of Science, Indianapolis, IN. 921 pp.

Tesch, D.G. 1982. Pre-Settlement M ap of Portage County, Wisconsin (1839-1853). M.S. Thesis, University of Wisconsin-Stevens Point, WI. 79 pp.

Thorne, J.F. 1993. Landscape ecology: A foundation for greenway design, pp 23-42. In Smith, D.S., and P.C. Hellmund (Eds.). Ecology of Greenways: Design and Function of Linear Conservation Areas. University of Minnesota, Minneapolis, M N. 222 pp.

USDA Soil Conservation Service. 1978. Soil Survey of Portage County, Wisconsin. Washington, DC. 96 pp.

Willems, T.L. 1998. GIS Predictive Modeling of Prehistoric Site Distributions in Central Wisconsin. M.S. Thesis, University of Wisconsin-Milwaukee, WI.

W isconsin Department of Natural Resources. 1995. Wisconsin's Forestry Best Management Practices for Water Quality. Publication number FR093. 76 pp. 
Acknowledgments. We thank the Wisconsin Department of $\mathrm{N}$ atural Resources, particularly Don Kissinger, and the City of Stevens Point, particularly Mickey Simmons, for the project's funding support. We are also grateful to the Portage County Planning and Zoning Department, especially Dan Mahoney and Norm Bushor, and the Land Records Department, especially Cindy W isinski, for providing data and insights regarding long-term planning considerations for the project. Mark Dwyer gathered most of the baseline land use and zoning data used in the project, and Don Roppolo provided invaluable field assistance. And a special thank-you goes out to the founding members of People for Greenspace in Portage County, especially Leo Jacoby, Kathy Powell, and Mike Champion.

${ }^{1}$ Community Involvement Coordinator

Vermont U rban \& Community Forestry Program

UVM Extension

617 Comstock Road, Suite 5

Berlin, VT 05602-9194, U.S.

$2^{*}$ Professor of F orestry

College of Natural Resources

U niversity of W isconsin-Stevens Point (retired)

Current address:

5613 Styron Drive

Oriental, NC 28571, U.S.

${ }^{*}$ Corresponding author.

Résumé. Les espaces verts communautaires produisent des bénéfices écologiques, sociaux et économiques, mais ces bénéfices sont souvent oubliés dans le processus de développement du territoire. Avec l'accroissement des pression liées à l'expansion, les territoires non développés sont convertis à d'autres usages, et ce souvent avec peu de soucis pour les parcelles ayant un bon potentiel de préservation comme espace vert. Cet article fournit une méthodologie pour localiser les espaces verts de grande valeur. Au moyen d'un cas d'étude situé à Stevens Point au W isconsin, les espaces verts significatifs ont été identifiés en évaluant leur superficie, leur composition et la localisation des peuplements forestiers, des milieux humides et des prairies, et ce à l'intérieur et tout autour de la zone urbanisée. Les valeurs écologique, récréative et esthétique de chaque parcelle ont été évaluées et le processus en quatre étapes suivant pour établir les priorités a été développé: (1) définition de la portée du projet, (2) collecte des données et cartographie au moyen d'un système d'information géographique, (3) analyse des données et classification des parcelles, (4) couverture des territoires protégés. La technologie des systèmes d'information géographique a été utilisée comme outil pour recueillir, emmagasiner et analyser spatialement les données du projet.

Zusammenfassung. Der kommunale Grünbereich liefert ökologische, soziale und ökonomische Vorteile, die aber oft bei dem Landentwicklungsprozeß übersehen werden. Mit intensiviertem Wachstumsdruck wird unentwickeltes Land eher anderen Nutzungen zugeführt mit wenig Beachtung für die Parzellen, die für Grünbereiche besser geeignet wären. Diese Studie liefert eine M ethodologie zur Lokalisierung wertvoller Grünbereiche. Mit Stevens Point, W isconsin als Fallstudie wurden bedeutende Grünbereiche durch die Untersuchung von Größe, Zusammensetzung und Lage der Wälder, Überschwemmungsgebiete, Grassteppen in und um die urbanisierte Fläche identifiziert. Der ökologische und ästhetische Wert sowie der Wert für Freizeitgestaltung auf jeder Parzelle wurde bewertet und die folgenden 4-WerteProzeßfolge für Prioritätsfeststellung entwickelt: (1) Ziel des Projekts, (2) Datensammlung und GIS-Plan-Entwicklung, (3) Datenanalyse und Rangordnung der Parzellen, (4) Ausweisung von geschütztem Land. Die GIS-Technologie wurde hierbei benutzt, um die projektspezifischen Daten zu sammeln, speichern und entsprechend zu analysieren.

Resumen. Los espacios verdes urbanos proporcionan beneficios ecológicos, sociales y económicos. Sin embargo, estos beneficios son pasados por alto en los procesos de planeación. A medida que se intensifica el crecimiento, los terrenos son convertidos a otros usos, con frecuencia con muy poco miramiento hacia las parcelas mejor localizadas para la preservación de los espacios verdes. Este trabajo proporciona una metodología para la local ización de áreas verdes de gran valor. Utilizando un caso de estudio en Stevens Point, W isconsin, U.S. se identificaron áreas significativas, evaluando el tamaño, composición y localización de bosques, humedales y pastizales dentro y alrededor de un área urbanizada. Los valores ecológicos, recreativos y estéticos fueron valorados para cada parcela que fue clasificada. Fueron priorizados los siguientes cuatro pasos en el proceso de desarrollo: (1) definición de los alcances del proyecto; (2) colecta de datos y desarrollo de un SIG; (3) análisis de datos y clasificación de parcelas; y (4) definición de áreas protegidas. La tecnología de los Sistemas de Información Geográfica (SIG) fue usada como una herramienta para colectar, almacenar y analizar espacialmente los datos del proyecto. 